\title{
Sibbald Research Wetland: Mountain peatland form and ecohydrologic function as influenced by beaver
}

\author{
by Cherie J. Westbrook ${ }^{1 *}$ and Angela Bedard-Haughn²
}

\section{ABSTRACT}

Sibbald Research Wetland is a $1.3 \mathrm{~km}^{2}$ peatland in the foothills of the Rocky Mountains. The primary research foci are 1) the influence of beaver ponds on mountain peatland hydrology and 2) the potential influence of climate change on these beaver-impacted peatlands. This paper summarizes initial results and implications of the research.

\section{RÉSUMÉ}

Le site de recherche de Sibbald sur les milieux humides est une tourbière de $1,3 \mathrm{~km}^{2}$ située au pied des Rocheuses. Les principaux axes de recherche portent sont 1) l'influence des étangs de castor sur l'hydrologie des tourbières en montagne et 2) l'influence que pourraient avoir les changements climatiques sur ces tourbières affectées par le castor. Cet article donne un aperçu des résultats préliminaires et de leur implication sur les travaux de recherche.

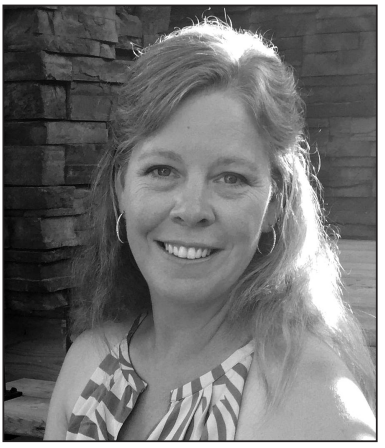

Cherie J. Westbrook

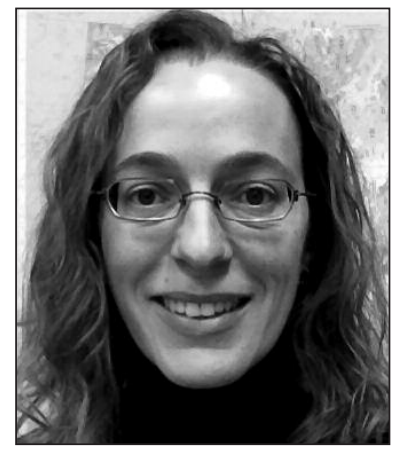

Angela Bedard-Haughn

\section{Introduction}

The Sibbald Research Wetland (Table 1; Fig. 1) was established in 2006 with the overarching goal of understanding the influence of beaver on mountain peatland form and ecohydrological functioning. An improved understanding of how both present and historical beaver ponds are affecting modern-day peat characteristics and hydrology are essential to determine and model how different climate futures will affect these important source areas (Table 2). Key questions that need to be answered, for example, include:

- How important are beaver ponds in peatlands to sustaining the low flow regime of mountain streams?

- How will the different climate futures influence beaver populations and how will such fluctuations impact resilience of the hydrological and soil-forming processes of mountain peatlands?

- Will changes release massive amounts of greenhouse gases and/or nutrients into streamflow?

\section{Important Scientific Advancement}

Beaver dams, even very small ones that are wholly contained in the stream channel, greatly enhance the amount of stream water flowing into the stream bed and banks - this water is typically discharged back to the stream somewhere downstream (Janzen and Westbrook 2011). These beaver-influenced flowpaths bring nitrogen-rich water back to the often low productivity streams (Shaw 2009).

The amount of water stored in beaver ponds can be accurately approximated using the algorithm Hayashi and van der Kamp (2000) developed for prairie pothole wetlands, which was simplified by Minke et al. (2010).

Our recent work (Morrison et al. 2015) shows that, within the greater Kananaskis region, nearly all peatlands in the mountains and $63 \%$ of peatlands in the foothills are impacted by beaver. The frequency impact in the region varies by management zone. Further, wetlands (peat- or mineral-based) with beaver impacts have much more open water than those without beaver impacts $\left(3.9 \mathrm{~km}^{2}\right.$ vs. $\left.0.4 \mathrm{~km}^{2}\right)$.

\section{Management/Operational Results}

Beaver have a large control on peatland form and hydrological functioning in this region, affecting processes such as the delivery of water and nutrients to downstream environments under both peak and low flow conditions. Additionally, different beaver management practices drive the degree to which beaver modify the wetlands. As a result, beaver management requires recognition of the critical hydrologic roles played by beaver in the region.

\footnotetext{
${ }^{1}$ Department of Geography and Planning, University of Saskatchewan, Saskatoon, Saskatchewan, Canada S7N 5C8; ${ }^{\star}$ corresponding author: cherie.westbrook@usask.ca

${ }^{2}$ Department of Soil Science, College of Agriculture and Bioresources, Saskatoon, Saskatchewan, Canada S7N 5A8
} 
Table 1: Description of the study area

\begin{tabular}{ll}
\hline & Watershed location data \\
\hline $\begin{array}{l}\text { Location } \\
\text { (descriptive) }\end{array}$ & $\begin{array}{l}\text { The foothills of the Rocky Mountains, } \\
\text { approximately } 70 \text { km west of Calgary }\end{array}$ \\
$\begin{array}{l}\text { Location } \\
\text { (geographic) }\end{array}$ & $51^{\circ} 03^{\prime} 29.38^{\prime \prime} \mathrm{N}, 114^{\circ} 52^{\prime} 11.66^{\prime \prime} \mathrm{W}$ \\
Watershed area & Not yet available (peatland is $\sim 1.3 \mathrm{~km}^{2}$ ) \\
$\begin{array}{l}\text { Elevation range } \\
\text { (a.s.l.) }\end{array}$ & $1475-1653 \mathrm{~m}$ \\
$\begin{array}{l}\text { Precipitation } \\
\text { (mean annual) }\end{array}$ & $\begin{array}{l}\text { Institute, } 1975-2008) \\
\text { New year-round weather station as of fall } 2012\end{array}$ \\
$\begin{array}{l}\text { Runoff } \\
\text { (mean annual) }\end{array}$ & Not yet available \\
$\begin{array}{l}\text { Temperature } \\
\text { (mean annual) }\end{array}$ & $3.5^{\circ} \mathrm{C}$ (BGS Institute; 1975-2008) \\
\hline
\end{tabular}

Table 2: Data collected in the Sibbald Research Wetland

\begin{tabular}{ll}
\hline Study type & Research design \\
\hline Treatments & $\begin{array}{l}\text { A variety of ecohydrological and soil sci- } \\
\text { ence studies ongoing }\end{array}$ \\
Controls & Varies by individual project \\
Study duration & Varies by individual project \\
Variables measured & $\begin{array}{l}\text { Hyporheic flow, groundwater level and } \\
\text { flows, year-round water balance, beaver } \\
\text { pond stage, stream flows, ground pene- } \\
\text { trating radar, soil type, soil chemistry, } \\
\text { water chemistry (ions, N, P, conductivity) }\end{array}$ \\
\hline
\end{tabular}

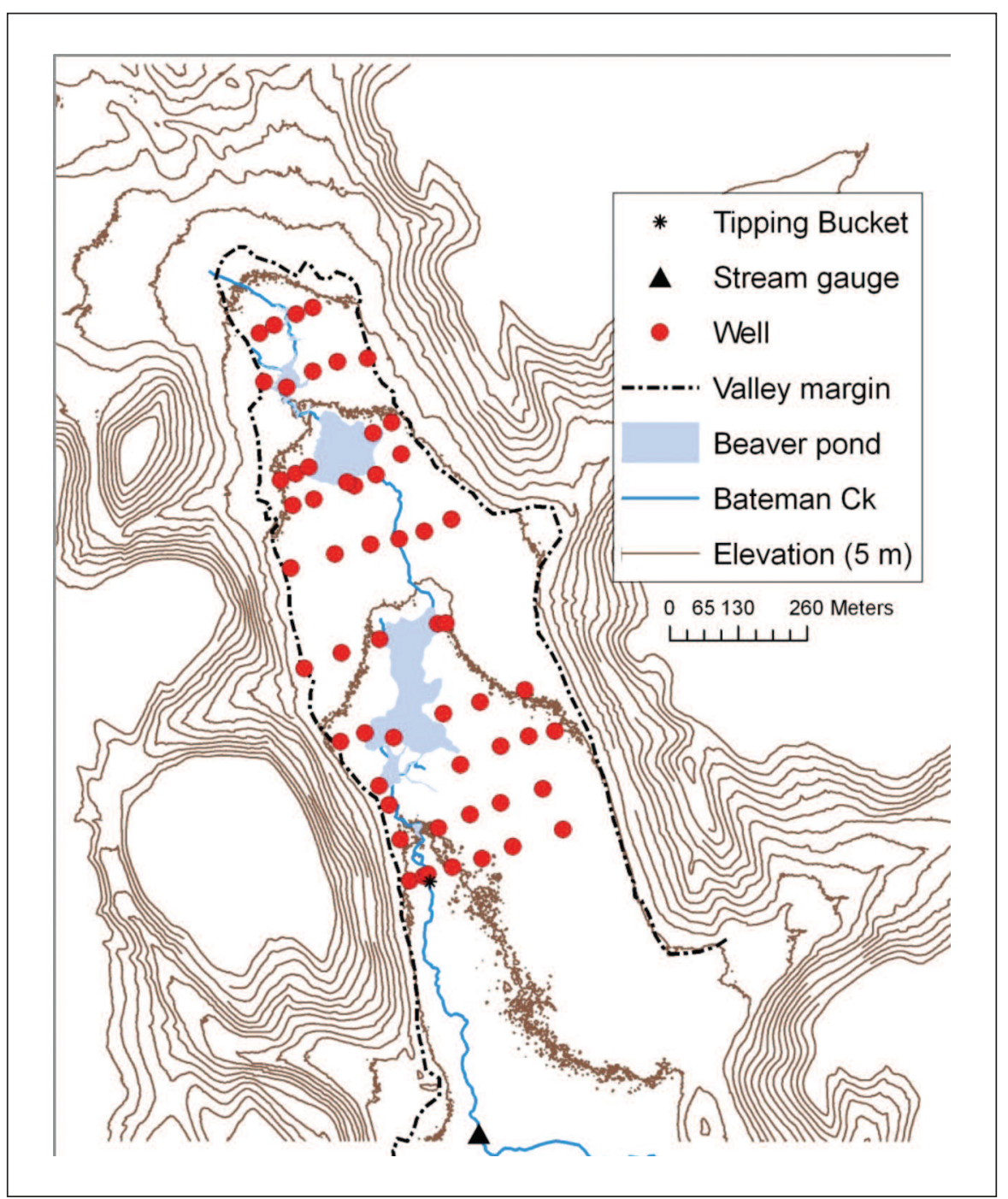

\section{References}

Hayashi, M. and G. Van der Kamp. 2000. Simple equations to represent the volume-area-depth relations of shallow wetlands in small topographic depressions. J. Hydrol. 237 (1): 74-85. doi:10.1016/S0022-1694(00)00300-0

Janzen, K. F. and C. J. Westbrook. 2011. Hyporheic flows along a channeled peatland: influence of beaver dams. Can. Water Resour. J. 36 (4): 331-347. doi: 10.4296/cwrj3604846

Minke, A. G., C.J. Westbrook and G. Van der Kamp. 2010. Simplified volume-area-depth method for estimating water storage of prairie potholes. Wetlands 30 (3): 541-551. DOI 10.1007/ s13157-010-0044-8

Morrison, A., C.J. Westbrook and A. Bedard-Haughn. 2015. Distribution of Canadian Rocky Mountain wetlands impacted by beaver. Wetlands 35: 95-104. DOI 10.1007/s13157-0140595-1

Shaw, E.L. 2009. Lateral exchange of water and nitrogen along a beaverdammed stream draining a Rocky Mountain valley. MSc thesis, University of Saskatchewan, $73 \mathrm{p}$.

Fig. 1. Study area with locations of tipping buckets to measure precipitation inputs, stream gauging sites to measure discharge, and wells to measure depth to subsurface water. 